\title{
KUALITAS SEMEN CAIR SAPI SIMENTAL MENGGUNAKAN LARUTAN ISOTONIS KOMERSIAL PADA KONSENTRASI DAN LAMA PENYIMPANAN BERBEDA
}

\author{
B. A. MARDIAN., ZUMARNI DAN A. E HARAHAP \\ Fakultas Pertanian dan Peternakan Universitas Islam Negeri Sultan Syarif Kasim Riau \\ Jln. H. R Soebrantas KM 16 Panam - Pekanbaru \\ Email : bayuankemardian@gmail.com
}

\begin{abstract}
This study aimed to examine the interaction between the concentration and duration of storage of diluent solution isotonic different to the quality of spermatozoa bull simental. This research was conducted at the Regional Technical Implementation Unit of Artificial Insemination Centres (UPTD BIB) Tuah Sakato, Payakumbuh. In April 2016. This study used a randomized block design (RAK) factorial design to Factor $A$ (Concentration LIK) ie A1 = $100 \mathrm{ml}$ Tris Egg Yolk, A2 = $(60 \mathrm{ml})$ Tris Egg Yolk + $(40 \mathrm{ml}) \mathrm{LIK}, \mathrm{A3}=(55 \mathrm{ml})$ Tris Egg Yolk + $(45 \mathrm{ml}) \mathrm{LIK}, A 4=(50 \mathrm{ml})$ Tris Egg Yolk + $(50 \mathrm{ml}) \mathrm{LIK}$, and factor $B$ (retention) is $B 1=0$ day, B2 =1, B3 = 2 day, days, $B 4=3$ days. Each treatment consists of three replicates. Parameters measured were motility, percentage of survival, abrnormalitys, and Plasma Membrane Integrity. These results indicate that an isotonic solution can be used as an alternative Commercial diluent with the best results on the percentage LIK $40 \mathrm{ml}$, but the effectiveness of the efficiency of storage use was only on the first day (24 hours).
\end{abstract}

keywords : catle simental, commercial isotonic solution, motility, percentage of survival, abnormalities, plasma membran,integrity.

\section{PENDAHULUAN}

Kemajuan bioteknologi peternakan dewasa ini diarahkan dalam bidang reproduksi salah satunya adalah Inseminasi Buatan (IB). Inseminasi Buatan adalah teknik memasukkan spermatozoa atau semen jantan yang telah dicairkan dan diproses terlebih dahulu ke dalam saluran kelamin betina menggunakan metode dan alat khusus yang disebut insemination gun (Toelihere, 1993).

Salah satu faktor yang mendukung keberhasilan IB adalah tingginya kualitas semen yang digunakan (Norman et al., 2003). Keberhasilan IB tidak hanya tergantung pada kualitas dan kuantitas semen yang diejakulasikan, tetapi tergantung juga kepada kualitas bahan bahan pengencer yang digunakan (Solihati dan Kune, 2009).

Untuk menghasilkan semen beku yang berkualitas tinggi dibutuhkan bahan pengencer semen yang mampu mempertahankan kualitas spermatozoa selama proses pendinginan, pembekuan, maupun pada saat thawing (Arifiantini dan Yusuf, 2010). Oleh sebab itu bahan pengencer semen harus mengandung sumber nutrisi, buffer, bahan anti cold shock, antibiotik, dan krioprotektan yang dapat melindungi spermatozoa selama pembekuan dan thawing (Solihati dan Kune, 2009). Bahan pengencer yang digunakan untuk meningkatkan jumlah semen sapi antara lain susu skim, kuning telur, sitrat serta bahan yang berasal dari buah-buahan dengan syarat tidak beracun, berenergi, mampu mempertahankan kualitas semen, bersifat melindungi, memiliki keasaman yang sesuai dan isotonis terhadap spermatozoa (Hardijanto et al., 2010).

Pengencer kuning telur sitrat digunakan sebagai media hidup spermatozoa, karena semen mengandung asam sitrat yang merupakan penyangga bersifat isotonis, berguna bagi metabolisme sel, sebagai buffer dalam mempertahankan $\mathrm{pH}$ dan daya hidup spermatozoa. Selanjutnya asam sitrat akan mengikat logam kalsium dan logam berat lainya serta mengkogulasikan butir-butir lemak pada kuning telur saat pembekuan berlangsung, sehingga spermatozoa mudah diobservasi dengan baik (Herdiawan, 2004). 
Salah satu minuman yang mengandung asam sitrat adalah Pocari Sweat, dalam penelitian ini akan disebut Larutan Isotonis Komersial (LIK). Berdasarkan penelitian Ichmy (2010), didapatkan $\mathrm{pH}$ LIK Kuning Telur (LIKKT) sebesar 6,3 (pH LIKKT hampir mendekati $\mathrm{pH}$ semen sapi simental yaitu 5,9-7,3 (Susilawati dkk., 1993). Diharapkan pengencer LIK dapat mempertahankan motilitas dan persentase hidup spermatozoa sapi simmental. Salah satu unsur yang terkandung dalam LIK adalah citrate $^{3-}$ 10,0 $\mathrm{mEq} / \mathrm{L}$ (Pocari Sweat, 2015) yang artinya sama dengan $1,92 \%$ dalam $100 \mathrm{ml}$ sedangkan jumlah citrate yang digunakan dalam perlakuan kontrol sebanyak $2,9 \%$.

Pada penelitian Ichmy (2010) penggunaan bahan pengencer 1:4 (LIK+Kuning Telur) hasilnya tidak memberikan pengaruh nyata terhadap motilitas spermatozoa domba, tetapi pada perlakuan bahan pengencer 1:2:2 (kuning telur + LIK + tris) persentase motilitas yang didapat adalah $51 \%$, sedangkan tris kuning telur persentase motilitas yang didapat adalah 51,1\%, dimana kedua bahan pengencer tersebut tidak berbeda nyata.

\section{MATERI DAN METODE}

\section{Tempat dan Waktu}

Penelitian dilakukan pada bulan April 2016 di Balai Inseminasi Buatan (BIB) Tuah Sakato, Payakumbuh, Sumatera Barat.

\section{Materi}

Materi yang digunakan dalam penelitian ini adalah semen segar sapi simental yang ditampung langsung di Balai Inseminasi Buatan Tuah Sakato, Payakumbuh.

Bahan yang digunakan dalam penelitian ini adalah larutan isotonis komersial/LIK kuning telur, tris, antibiotik (streptomycin dan penicillin), gliserol, zat warna eosin dan aquabidest.

Alat-alat yang digunakan adalah vagina buatan (VB) untuk menampung semen, waterbath, mikroskop elektrik, photometer SMDS, timbangan analitik, spatula, gelas ukur, gelas obyek, cover glass, kertas lakmus, filling dan sealing, kertas saring, erlemeyer, alumunium foil, mikropipet, dan rak tabung reaksi.

\section{Metode}

Materi yang digunakan dalam penelitian ini adalah semen segar sapi simmental yang bernama zelook yang ditampung langsung di Balai Inseminasi Buatan Tuah Sakato, Payakumbuh.

Penelitian ini menggunakan metode eksperimen dengan Rancangan Acak Kelompok (RAK) pola faktorial dengan 2 faktor $(4 \times 4)$ dan 3 ulangan.

Faktor A konsentrasi LIK pada pengencer A1 $=(100 \mathrm{ml})$ Tris Kuning Telur A2 $=(60 \mathrm{ml})$ Tris Kuning Telur $+(40 \mathrm{ml})$ LIK A3 $=(55 \mathrm{ml})$ Tris Kuning Telur $+(45 \mathrm{ml})$ LIK A4 $=(50 \mathrm{ml})$ Tris Kuning Telur $+(50 \mathrm{ml})$ LIK

Faktor B adalah lama penyimpanan ;
$\mathrm{B} 1=0$ hari
B3 $=2$ hari
$\mathrm{B} 2=1$ hari
$\mathrm{B} 4=3$ hari.

\section{Pembuatan pengencer sesuai perlakuan :}

a) pembuatan perlakuan A1 :

diambil larutan campuran tris $74 \mathrm{ml}$ dicampur kuning telur $20 \mathrm{ml}$, gliserol $6 \mathrm{ml}$ setelah itu tambahkan antibiotik (penisilin 0,5 $\mathrm{ml}$ dan 0,4 $\mathrm{ml}$ ) sehingga menjadi $100 \mathrm{ml}$ dan dihomogenkan dengan stir magnetik.

b) Pembuatan perlakuan A2 :

LIK diambil $40 \mathrm{ml}$, dan ditambahkan larutan campuran Tris $40 \mathrm{ml}$ sehingga menjadi $80 \mathrm{ml}$, selanjutnya dicampurkan kuning telur $20 \mathrm{ml}$, setelah itu tambahkan antibiotik (penisilin 0,5 dan streptomycin 0,4) sehingga larutan menjadi menjadi 
$100 \mathrm{ml}$ dan dihomogenkan dengan stir magnetik.

c) Pembuatan perlakuan A3 :

LIK diambil $45 \mathrm{ml}$, dan ditambahkan larutan campuran Tris $35 \mathrm{ml}$ sehingga menjadi $80 \mathrm{ml}$, selanjutnya dicampurkan kuning telur $20 \mathrm{ml}$, setelah itu tambahkan antibiotik (penisilin 0,5 dan streptomycin 0,4) sehingga larutan menjadi menjadi $100 \mathrm{ml}$ dan dihomogenkan dengan stir magnetik.

d) Pembuatan perlakuan A4 :

LIK diambil $50 \mathrm{ml}$, dan ditambahkan larutan campuran Tris $30 \mathrm{ml}$ sehingga menjadi $80 \mathrm{ml}$, selanjutnya dicampurkan kuning telur $20 \mathrm{ml}$, setelah itu tambahkan antibiotik (penisilin 0,5 dan streptomycin 0,4) sehingga larutan menjadi menjadi $100 \mathrm{ml}$ dan dihomogenkan dengan stir magnetik.

\section{Peubah yang Diukur}

\section{Persentase Motilitas}

Penentuan motilitas spermatozoa dilakukan menurut gerakan individual (Shukla, 2011), yaitu dengan meneteskan semen pada gelas objek yang bersih dan ditutup dengan gelas penutup.Kemudian dilakukan pengamatan di bawah mikroskop dengan pembesaran $45 \mathrm{x}$ 10. Kemudian dihitung gerakan individual spermatozoa.

\section{Persentasi Spermatozoa Hidup}

Jumlah spermatozoa yang hidup dihiting dengan cara mengaduk semen dalam tabung lalu meneteskan semen pada gelas obyek lalu dicampur dengan zat warna eosin-Negrosin kemudian dibuat preparat ulas, difiksasi di atas api. Pengamatan dilakukan atas spermatozoa yang hidup pada lima kali lapangan pandang dengan perbesaran 400 kali kemudian dirata-rata. Pada spermatozoa yang hidup tidak akan terwarnai oleh zat warna. Spermatozoa yang telah mati akan rusak akan berwarna merahkeunguan. Pengambilan data untuk jumlah spermatozoa yang hidup dilakukan melalui pemeriksaan hidup spermatozoa dengan metode pewarnaan eosin negrosin setiap kali melakukan percobaan. Guna menentukan persentase sperma tozoa yang hidup menggunakan rumus (Shukla, 2011) :

\section{Persentase Abnormalitas}

Abnormalitas spermatozoa diamati dengan membuat preparat ulas pada gelas objek dari satu tetes sperma yang dicampur dengan satu eosinNegrosin. Pengamatan dilakukan di bawah mikroskop dengan pembesaran $45 \times 10$. Spermatozoa yang normal dan abnormal dihitung 100 sampai 200 sel (Shukla, 2011).

\section{Persentase Membran Plasma Utuh} (MPU)

Dilakukan dengan menggunakan Hypoosmotic Swelling Test. Prosedur yang digunakan mengikuti petunjuk Jayendran et al., (1984) yaitu menggunakan medium Hos Test berupa $\mathrm{NaCl}$ hipotonik $(0,031 \mathrm{~m}$; terbuat dari $0,179 \mathrm{~g} \mathrm{NaCl}$ yang dilarutkan dengan $100 \mathrm{ml}$ akuabides). Sebanyak 0,1 $\mathrm{ml}$ semen ditambah dengan 9,9 $\mathrm{ml}$ medium HOS Tes, selanjutnya diinkubasi selama satu jam pada suhu $37^{\circ} \mathrm{C}$ dalam water bath. Semen yang telah diinkubasi dievaluasi dengan menggunakan mikroskop cahaya 40 kali. Jumlah spermatozoa yang dihitung adalah 200 dengan skala 0 sampai 100 persen.

\section{HASIL DAN PEMBAHASAN}

\section{Evaluasi Semen Segar}

Hasil pengamatan semen segar setelah penampungan selama penelitian dapat dilihat pada Tabel 1. 
Tabel 1.Hasil pengamatan karakteristik semen segar sapi simental

\begin{tabular}{lcccc}
\hline \multicolumn{1}{c}{ Karakteristik } & \multicolumn{4}{c}{ Penampungan } \\
Nama sapi & Zelook & Zelook & Zelook & Zelook \\
Umur & 7 thn & 7 thn & 7 thn & 7 tahun \\
Makroskopis Semen: & & \multicolumn{2}{c}{} & \\
Volume (ml) & 8 & 9 & 8 & 8,33 \\
pH & 6,8 & 6,5 & 6,8 & 6,7 \\
Warna & Krem & Krem & Krem & Krem \\
Konsistensi & Kental & Sedang & Kental & Kental \\
Mikroskopis Semen: & & & & \\
Konsentrasi (juta sel/ml) & 1,800 & 1,700 & 1,800 & 1,767 \\
Gerak Massa & +++ & ++ & +++ & +++ \\
Gerak Individu & 3 & 2 & 3 & 3 \\
Motilitas (\%) & 75,00 & 72,00 & 75,00 & 74,00 \\
Sel Hidup (\%) & 80,50 & 78,00 & 81,00 & 79,83 \\
Abnormalitas (\%) & 7,58 & 8,25 & 7,72 & 7,85 \\
MPU (\%) & 81,50 & 79,49 & 81,88 & 81,50 \\
\hline
\end{tabular}

Sumber : Hasil Penelitian,(2016).

\section{Pemeriksaan Secara Makroskopis}

\section{Pemeriksaan Volume}

Dari Tabel 1. dapat dilihat rataan volume semen yang diperoleh pada saat penelitian mencapai $8,33 \mathrm{ml}$. Hal ini sesuai dengan pendapat Toelihere (1993) yaitu volume semen sapi bervariasi 1,0 sampai $15,0 \mathrm{ml}$, tetapi lebih rendah dari hasil pengamatan Wiyanto et al (2014) yaitu volume semen yang dihasilkan oleh sapi simental rata-rata 9,03 $\pm 2,08$. Perbedaan volume ini kemungkinan dipengaruhi oleh faktor umur, ukuran badan, tingkatan makanan, frekuensi penampungan atau ejakulat (Toelihere, 1993).

\section{Pemeriksaan Warna}

Warna semen segar sapi simental (Zelook) yang diperoleh yaitu krem. Hal ini memenuhi syarat kelayakan semen segar untuk diproduksi menjadi semen segar yaitu berwarna susu, krem dan kekuning-kuningan Toelihere (1993). Nursyam (2007) menyatakan semen sapi normal berwarna putih susu atau krem keputihan dan keruh. Semen segar yang memiliki jumlah spermatozoa banyak akan mengakibatkan semen lebih kental dan warna lebih pekat (Souhoka $d k k$., 2009).

\section{Pemeriksaan $\mathrm{pH}$}

Derajat keasaman $(\mathrm{pH})$ semen pada tiga kali penampungan berkisar 6,5-6,8 hasil ini masih tergolong kondisi normal untuk semen sapi. Hal ini sesuai pendapat Toelihere (1993) yaitu $\mathrm{pH}$ semen sapi berkisar 6,2-7,5 dengan rata-rata 6,8.

\section{Pemeriksaan Secara Mikroskopis}

\section{Pemeriksaan Gerakan Massa}

Berdasarkan hasil pengamatan selama penelitian pada seekor sapi simental dari tiga kali penampungan diperoleh satu kali penampungan semen mempunyai gerakan massa baik $(++)$ dan dua kali penampungan mempunyai gerakan massa sangat baik $(+++)$. Pada spermatozoa yang gerakan massanya +++ (sangat baik) terlihat gelombang-gelombang yang besar, gelap, banyak, tebal dan aktif. Hal ini sesuai dengan pendapat Toelihere (1993) bahwa spermatozoa dalam satu kelompok mempunyai kecendrungan untuk bergerak bersama-sama kesatu arah merupakan gelombang-gelombang yang tebal atau tipis, bergerak cepat atau 
lambat tergantung dari konsentrasi sperma hidup didalamnya.

\section{Gerakan Individu}

Gerakan individu hasil dari
pemeriksaan dalam penelitian ini
diperoleh hasil dengan angka penilaian
yang ketiga yaitu bergerak progresif yang
gesit dan membentuk gerakan massa
dengan motilitas $75 \%, 72 \%$ dan $75 \%$ untuk
semen segar sapi Zelook. Hal ini sesuai
dengan pendapat Toelihere (1981) bahwa
penilaian kualitas semen yang ketiga
sangat baik yaitu 50\% sampai $80 \%$
spermatozoa bergerak progresif dan
menghasilkan gerakan massa.

\section{Konsentrasi}

Dalam penelitian didapatkan hasil rataan konsentrasi spermatozoa 1,767 juta/ml. Hasil penelitian ini menunjukan semen sapi layak untuk diproses lebih lanjut. Hal ini sesuai dengan Toelihere (1993), bahwa konsentrasi semen sapi dengan konsistensi kental berwarna krem mempunyai konsentrasi 1000 sampai 2000 juta atau lebih sel spermatozoa per $\mathrm{ml}$. Konsentrasi sapi simental dalam penelitian ini lebih kecil dibandingkan hasil pengamatan Said et al., (2005) yang mendapatkan 1790 juta/ml spermatozoa. Konsentrasi spermatozoa dipengaruhi oleh besarnya testes yang dimiliki sapi jantan, dalam satu gram tenunan testikuler menghasilkan rata-rata $9 \times 10^{6}$ per hari yaitu kira-kira 6000 sel per menit (Toelihere, 1993).

\section{Motilitas}

Rataan motilitas spermatozoa sapi simental menggunakan pengencer LIK dan lama penyimpanan dapat dilihat pada Tabel 2.

Pada (Tabel 2.) dapat dilihat konsentrasi LIK dan lama penyimpanan yang berbeda memberikan interaksi terhadap motilitas spermatozoa, dimana semakin tinggi konsentrasi LIK yang ditambahkan dan semakin lama waktu penyimpanan menyebabkan berkurangnya motilitas spermatozoa sapi simental. Hasil penelitian menunjukan pada konsentrasi $40 \mathrm{ml}$ LIK dengan lama penyimpanan satu hari (24 jam) mampu memberikan motilitas $52,00 \pm 2,29 \%$ namun penurunan motilitas lebih tinggi terjadi pada konsentrasi $45 \mathrm{ml}$ LIK dan $50 \mathrm{ml}$ LIK.

Hal ini diduga disebabkan oleh $\mathrm{pH}$ campuran LIK dan tris kuning telur yang berkisar 6,2-6,3 masih terlalu asam bagi spermatozoa sedangkan $\mathrm{pH}$ sapi simental yang diperoleh 6,5-6,8 sehingga semakin lama waktu penyimpanan dengan konsentrasi LIK yang meningkat menyebabkan motilitasnya menurun. Hal ini sesuai dengan pendapat (Sugiarti et al., 2004) bahwa penyimpanan dalam jangka waktu lama menyebabkan penurunan motilitas spermatozoa akibat asam laktat sisa metabolisme sel yang menyebabkan kondisi medium menjadi semakin asam karena penurunan $\mathrm{pH}$ dan kondisi ini dapat bersifat racun terhadap spermatozoa, yang akhirnya menyebabkan kematian spermatozoa.

Pernyataan ini didukung oleh Beraden dan Fuquay (1984) bahwa motilitas spermatozoa pada semen dingin mengalami penurunan disebabkan karena pada proses metabolisme yang terus menerus berjalan selama penyimpanan akan menyebabkan energi berkurang sehingga motilitas spermatozoa semakin lama semakin menurun selain itu dengan adanya metabolisme pada kondisi anaerob (fruktolisis) secara terus menerus menimbulkan asam laktat sehingga akan menurunkan $\mathrm{pH}$ yang menyebabkan motilitas menurun.

Pada penelitian ini bahan pengencer hanya mampu mempertahankan motilitas hingga hari kesatu saja yang mana diperoleh motilitas yang tertinggi pada perlakuan pembanding yakni pada konsentrasi $0 \mathrm{ml}$ dengan persentase

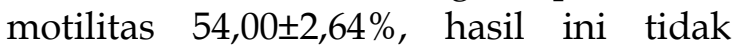
berbeda nyata dengan perlakuan $40 \mathrm{ml}$ LIK dengan persentase motilitas 
$52,00 \pm 2,29 \%$ hal ini disebabkan konsentrasi kuning telur sebagai sumber energi dan campuran LIK dan Tris sitrat sebagai buffer sudah isotonis sehingga spermatozoa dapat dengan mudah bergerak, namun berbeda sangat nyata $(\mathrm{P}<0,01)$ dengan perlakuan konsentrasi $45 \mathrm{ml}$ dan $50 \mathrm{ml}$ LIK yang memperoleh hasil motilitas pada hari pertama sebesar $43,17 \pm 2,02$ dan $38,00 \pm 2.59$, hal ini disebabkan semakin tinggi konsentrasi LIK yang ditambahkan maka akan semakin asam sehingga menyebabkan sedikitnya pergerakan spermatozoa motil.

Tabel 2. Rataan motilitas spermatozoa (\%) sapi simental menggunakan pengencer campuran LIK

\begin{tabular}{cccccc}
\hline \multirow{2}{*}{$\begin{array}{c}\text { Lama } \\
\text { Penyimpanan }\end{array}$} & \multicolumn{4}{c}{ Perlakuan Larutan Isotonis Komersial } & \multirow{2}{*}{ Rataan } \\
\cline { 2 - 5 } & $\mathbf{0 ~} \mathbf{~ m l}$ & $\mathbf{4 0} \mathbf{~} \mathbf{l}$ & $\mathbf{4 5} \mathbf{~ m l}$ & $\mathbf{5 0} \mathbf{~ m l}$ & \\
\hline 0 hari & $67.33^{\mathrm{Dd}} \pm 2.56$ & $65.17^{\mathrm{Db}} \pm 2.75$ & $62.00^{\mathrm{Dc}} \pm 3.46$ & $56.67 \mathrm{Da} \pm 1.52$ & $62.79 \pm 4.76$ \\
1 hari & $54.00^{\mathrm{Cd}} \pm 2.64$ & $52.00^{\mathrm{C}} \pm 2.29$ & $43.17^{\mathrm{Cb}} \pm 2.02$ & $38.00^{\mathrm{Ca}} \pm 2.59$ & $46.79 \pm 7.10$ \\
2 hari & $43.00^{\mathrm{B}} \pm 2.50$ & $41.67^{\mathrm{Bb}} \pm 1.75$ & $31.10^{\mathrm{Ba}} \pm 1.85$ & $29.33^{\mathrm{Ba}} \pm 2.08$ & $36.27 \pm 6.61$ \\
3 hari & $32.00^{\mathrm{Acd}} \pm 2.29$ & $32.33^{\mathrm{Ad}} \pm 2.25$ & $26.00^{\mathrm{Ab}} \pm 2.50$ & $20.17^{\mathrm{Aa}} \pm 1.89$ & $27.62 \pm 5.55$ \\
\hline Rataan & $49.08 \pm 13.84$ & $47.79 \pm 12.89$ & $40.56 \pm 14.63$ & $36.04 \pm 14.18$ & \\
\hline
\end{tabular}

Ket: Superskrip yang berbeda pada kolom (huruf kapital) dan baris (huruf kecil) yang sama menunjukkan berbeda nyata $(\mathrm{P}<0,01)$.

\section{Persentase Spermatozoa Hidup}

Rataan spermatozoa hidup sapi simental menggunakan pengencer LIK dan lama penyimpanan dapat dilihat pada Tabel 3.

Pada (Tabel 3.) dapat dilihat konsentrasi LIK dan lama penyimpanan yang berbeda memberikan interaksi terhadap persentase hidup spermatozoa, Hasil penelitian menunjukan pada hari ketiga persentase hidup spermatozoa tertinggi didapatkan pada konsentrasi $40 \mathrm{ml}$ LIK yaitu $51,33 \pm 2,08 \%$ hasil ini tidak berbeda nyata dengan konsentrasi $0 \mathrm{ml}$
LIK yakni 50,50 $\pm 1,50$ hal ini disebabkan konsentrasi kuning telur sebagai sumber energi dan campuran LIK dan Tris sitrat sebagai buffer sudah isotonis, namun berbeda nyata dengan $(\mathrm{P}<0,01)$ perlakuan konsentrasi $45 \mathrm{ml}$ dan $50 \mathrm{ml}$ LIK dengan persentase $41,17 \pm 1,25$ dan $39,17 \pm 1,25$, dari hasil penelitian ini dapat dilihat konsentrasi LIK yang meningkat dan waktu penyimpanan yang berbeda menyebabkan menurunnya persentase hidup spermatozoa sapi simmental.

Tabel 3. Rataan spermatozoa hidup (\%) sapi simmental menggunakan pengencer LIK

\begin{tabular}{lccccc}
\hline \multirow{2}{*}{$\begin{array}{c}\text { Lama } \\
\text { Penyimpanan }\end{array}$} & \multicolumn{4}{c}{ Perlakuan Larutan Isotonis Komersial } & \multirow{2}{*}{ Rataan } \\
\cline { 2 - 5 } 0 hari & $\mathbf{0 ~} \mathbf{~ l}$ & $\mathbf{4 0} \mathbf{~ m l}$ & $\mathbf{4 5} \mathbf{~ m l}$ & $\mathbf{5 0} \mathbf{~ m l}$ & \\
1 hari & $77.50^{\mathrm{Dd}} \pm 2.29$ & $76.83^{\mathrm{Dcd}} \pm 2.46$ & $75.83^{\mathrm{Db}} \pm 2.92$ & $73.83^{\mathrm{Da}} \pm 2.92$ & $76.00 \pm 2.69$ \\
2 hari & $61.17^{\mathrm{C}} \pm 1.04$ & $70.50^{\mathrm{C}} \pm 1.80$ & $66.00^{\mathrm{Cb}} \pm 2.00$ & $60.83^{\mathrm{Ca}} \pm 1.60$ & $67.125 \pm 4.4$ \\
3 hari & $60.83^{\mathrm{Bd}} \pm 1.75$ & $61.67^{\mathrm{B}} \pm 1.75$ & $49.67^{\mathrm{Bb}} \pm 1.52$ & $45.00^{\mathrm{Ba}} \pm 3.50$ & $54.29 \pm 7.72$ \\
\hline Rataan & $50.50^{\mathrm{Ad}} \pm 1.50$ & $51.33^{\mathrm{Ac}} \pm 2.08$ & $41.17^{\mathrm{Ab}} \pm 1.25$ & $39.17^{\mathrm{Aa}} \pm 1.25$ & $45.54 \pm 5.82$ \\
\hline
\end{tabular}

Ket: Superskrip yang berbeda pada kolom (huruf kapital) dan baris (huruf kecil) yang sama menunjukkan berbeda nyata $(\mathrm{P}<0,01)$. 
Keadaan ini menunjukkan selama proses pengolahan dan penyimpanan terjadi perubahan fisik dan biokimia dari spermatozoa yang digunakan. Menurut Maxwell dan Watson (1996) pada proses pengolahan semen, masalah yang sering timbul biasanya rusaknya membran plasma akibat terbentuknya peroksidasi lipid. Rusaknya membran plasma akan menyebabkan penurunan motilitas spermatozoa dan akhirnya dapat berpengaruh terhadap persentase hidup spermatozoa.

Hal lain yang menyebabkan rendahnya persentase hidup pada spermatozoa karena di dalam LIK terdapat kandungan elektrolit sodium $\left(\mathrm{Na}^{+}\right)$, citrate ${ }^{3-}$, calium $\left(\mathrm{Ca}^{2+}\right)$, kalsium $\left(\mathrm{K}^{+}\right)$, dan chloride $(\mathrm{CI})$ yang merupakan zat-zat anorganik berperan penting dalam metabolisme semen dan sangat mempengaruhi keseimbangan osmosis semen. Zat anorganik seperti $\mathrm{Na}^{+}, \mathrm{Ca}^{2+}, \mathrm{K}^{+}$dan $\mathrm{Mg}^{+}$dalam plasma semen menpunyai peranan penting dalam metabolisme semen dan sangat mempengaruhi keseimbangan osmosis semen (Kaya, 2000).

Selain mengandung ion-ion LIK juga mengandung bahan lain yang dapat berpengaruh buruk terhadap spermatozoa jika dalam kadar yang tinggi, misalnya magnesium dan potasium. Selain itu juga terdapat Lactate dalam LIK, dimana laktat merupakan hasil metabolisme spermatozoa yang bersifat racun bagi spermatozoa bila kadarnya cukup tinggi dalam semen (Hardijanto $d k k$., 2010) penimbunan asam laktat akan menyebabkan $\mathrm{pH}$ semakin asam. Menurut Aurich (1987) dalam susunan asam konsentrasi $\mathrm{H}^{+}$meningkat semakin tinggi sehingga menyebabkan gangguan metabolisme sel sehingga energi yang dihasilkan tidak optimal dan menurunkan daya hidup spermatozoa itu sendiri.

Meskipun ada perlindungan dari lipoprotein yang terdapat dalam kuning telur namun semakin lama mediapun semakin menurun fungsi perlindunganya terhadap spermatozoa melawan dingin. Rendahnya perlindungan ini menyebabkan semakin banyak spermatozoa yang mati

\section{Persentase Abnormalitas}

Rataan abnormalitas spermatozoa sapi simental menggunakan pengencer LIK dan lama penyimpanan dapat bisa pada Tabel 4.

Tabel 4. Rataan abnormalitas spermatozoa (\%) sapi simental menggunakan pengencer LIK

\begin{tabular}{|c|c|c|c|c|c|}
\hline \multirow{2}{*}{$\begin{array}{c}\text { Lama } \\
\text { Penyimpanan }\end{array}$} & \multicolumn{4}{|c|}{ Perlakuan Larutan Isotonis Komersial } & \multirow{2}{*}{ Rataan } \\
\hline & $0 \mathrm{ml}$ & $40 \mathrm{ml}$ & $45 \mathrm{ml}$ & $50 \mathrm{ml}$ & \\
\hline 0 hari & $9.66^{\mathrm{Aa}} \pm 0.28$ & $11.33^{\mathrm{Aa}} \pm 0.76$ & $15.17^{\mathrm{Ab}} \pm 1.04$ & $18.33^{\mathrm{Ac}} \pm 0.76$ & $13.62 \pm 3.58$ \\
\hline 1 hari & $10.5^{\mathrm{Aa}} \pm 0.5$ & $12.83^{\mathrm{ABa}} \pm 0.76$ & $20.67^{B b} \pm 0.76$ & $24.50^{\mathrm{B}} \mathrm{c} \pm 0.86$ & $17.12 \pm 5.97$ \\
\hline 2 hari & $11.17^{\mathrm{Aa}} \pm 0.28$ & $13.67^{\mathrm{BCb}} \pm 0.76$ & $26.50^{C} \mathrm{c} \pm 0.50$ & $38.66^{\mathrm{Cd}} \pm 0.76$ & $22.50 \pm 11.49$ \\
\hline 3 hari & $12.67^{\mathrm{ABa}} \pm 0.28$ & $15.50^{\mathrm{Cb}} \pm 1.00$ & $33.67^{D} \pm \pm 3.78$ & $40.83^{\mathrm{Dd}} \pm 1.04$ & $25.66 \pm 12.54$ \\
\hline Rataan & $11.00 \pm 1.18$ & $13.33 \pm 1.72$ & $24.00 \pm 7.37$ & $30.58 \pm 9.90$ & \\
\hline
\end{tabular}

Ket: Superskrip yang berbeda pada kolom (huruf kapital) dan baris (huruf kecil) yang sama menunjukkan berbeda nyata $(\mathrm{P}<0,01)$.

Pada (Tabel 4.) dapat dilihat konsentrasi LIK dan lama penyimpanan yang berbeda memberikan interaksi terhadap abnormalitas spermatozoa, dimana konsentrasi LIK yang meningkat dan semakin lama waktu penyimpanan menyebabkan peningkatan abnormalitas spermatozoa sapi simental. Hasil penelitian menunjukan pada konsentrasi $40 \mathrm{ml}$ LIK dengan lama penyimpanan tiga hari mampu mempertahankan abnormalitas $15,50 \pm 1,00 \%$ hal ini masih dalam batas normal selama abnormalitas belum mencapai 20\%, namun hasil menunjukan berbeda nyata $(\mathrm{P}<0,01)$ pada konsentrasi $45 \mathrm{ml}$ LIK dan $50 \mathrm{ml}$ LIK 
dengan persentase $33,67 \pm 3,78 \%$ dan $40,83 \pm 1,04 \%$.

Diduga meningkatnya persentase abnormalitas dipengaruhi oleh lipoprotein yang terdapat dalam kuning telur yang semakin lama mediapun semakin menurun fungsi perlindunganya terhadap spermatozoa melawan dingin. Selain meningkatnya persentase abnormalitas spermatozoa diduga dipengaruhi oleh keadaan osmotik disekitarnya tidak sesuai (Damayanti, 1991). Hal ini sesuai dengan pendapat Kamal et al. (2005) dan Arifiantini et al. (2005) terjadinya peningkatan abnormalitas spermatozoa disebabkan oleh efek cekaman dingin (cold shock) dan ketidakseimbangan nutrisi. Toelihere (1981) menyatakan penambahan waktu penyimpanan menyebabkan derajat keasaman $(\mathrm{pH})$ semen menurun. Bentuk abnormal dari spermatozoa pada penelitian ini kebanyakan adalah abnormalitas sekunder seperti ekor bergulung, leher patah, kepala dan leher putus. Abnormalitas sekunder disebabkan perlakuan ketika pembuatan preparat ulas (Solihati dan Kune, 2009). Selain itu, juga ditemui bentuk abnormalitas primer seperti kepala kecil (microchepalic) dan ekor berganda.

\section{Persentase Membran Plasma Utuh (MPU)}

Rataan MPU spermatozoa sapi simental menggunakan pengencer LIK dan lama penyimpanan dapat dilihat pada Tabel 5.

Pada Tabel 5 dapat dilihat konsentrasi LIK dan lama penyimpanan yang berbeda memberikan interaksi terhadap MPU spermatozoa, dimana dengan konsentrasi LIK yang meningkat lama waktu penyimpanan menyebabkan menurunnya MPU spermatozoa sapi simental. Hasil penelitian menunjukan pada hari pertama (24 jam) dengan konsentrasi $40 \mathrm{ml}$ LIK masih mampu mempertahankan MPU $52,83 \pm 2,25 \%$, namun penurunan MPU lebih tinggi terjadi pada konsentrasi $45 \mathrm{ml}$
LIK dan $50 \mathrm{ml}$ LIK dengan persentase $42,33 \pm 2,08$ dan $37,00 \pm 3,46$.

Penurunan nilai MPU semakin rendah sesuai lama waktu penyimpanan hal ini disebabkan kuning telur yang mengandung lipoprotein dan lesitin untuk melindungi membran plasma spermatozoa ternyata tidak cukup mampu mempertahankan keutuhan membran plasma selain itu menurunnya membran plasma utuh saat ekuilibrasi disebabkan pada pengencer LIK bersifat asam tidak dapat mempertahankan keutuhan membran plasma setelah beberapa hari penyimpanan. Hal ini sesuai pendapat Beiley et al. (2000) perlakuan pendinginan dapat mengakibatkan membran plasma spermatozoa menjadi lebih permeabel sehingga mudah kehilangan enzim-enzim dan komponen-komponen yang terdapat dalam kepala sel. Sinha et al., (1996) menambahkan tingginya nilai integritas membran yang diperoleh pada plasma semen sapi disebabkan karena kemampuannya dalam melindungi membran plasma lebih baik sehingga hanya sedikit fosfolipid membran plasma sperma yang mengalami peroksidasi.

Akibat dari peroksidasi akan terbentuk peroksida lipid, yang bereaksi dengan radikal bebas dan merangsang terjadinya reaksi otokatilik yang menyebabkan rusaknya membran plasma. Pengencer LIK yang terbaik pada perlakuan $40 \mathrm{ml}$ dan $45 \mathrm{ml}$ dengan persentase membran plasma utuh $66,33 \%$ dan $63,50 \%$ persentase ini diperoleh pada waktu penyimpanan 0 hari, lebih kecil dibandingkan Bardan et al,. (2009) yang memperoleh persentase membran plasma utuh yaitu $74,31 \%$. Hal ini sesuai dengan Jayendran dan zeneveld (1986) jika dengan metode Hos-Tes diperoleh lebih $60 \%$ sperma yang menggembung maka dikatakan normal sedangkan $50-60 \%$ berarti tidak normal. 
Tabel 5. Rataan persentase membran plasma utuh semen sapi simental.

\begin{tabular}{cccccc}
\hline \multirow{2}{*}{$\begin{array}{c}\text { Lama } \\
\text { Penyimpanan }\end{array}$} & \multicolumn{4}{c}{ Perlakuan Larutan Isotonis Komersial } & \multirow{2}{*}{ Rataan } \\
\cline { 2 - 5 } $\mathbf{0 ~} \mathbf{~ l}$ & $\mathbf{4 0} \mathbf{~} \mathbf{l}$ & $\mathbf{4 5} \mathbf{~ m l}$ & $\mathbf{5 0} \mathbf{~ m l}$ & \\
\hline 0 hari & $70.66^{\mathrm{Dd}} \pm 1.52$ & $66.33^{\mathrm{Dc}} \pm 2.88$ & $63.50^{\mathrm{Db}} \pm 2.08$ & $55.00^{\mathrm{Da}} \pm 1.00$ & $63.87 \pm 6.33$ \\
1 hari & $57.33^{\mathrm{Cd}} \pm 3.05$ & $52.83^{\mathrm{C}} \pm 2.25$ & $42.33^{\mathrm{Cb}} \pm 2.08$ & $37.00^{\mathrm{Ca}} \pm 3.46$ & $47.30 \pm 8.77$ \\
2 hari & $49.67^{\mathrm{Bd}} \pm 1.52$ & $44.00^{\mathrm{B}} \pm 200$ & $30.17^{\mathrm{Bb}} \pm 1.04$ & $28.33^{\mathrm{Ba}} \pm 2.08$ & $38.04 \pm 9.55$ \\
3 hari & $41.17^{\mathrm{Ad}} \pm 1.75$ & $30.83^{\mathrm{Ac}} \pm 1.04$ & $25.33^{\mathrm{Ab}} \pm 2.08$ & $17.67 \mathrm{Aa} \pm 2.51$ & $28.75 \pm 9.08$ \\
\hline Rataan & $54.70 \pm 11.46$ & $48.50 \pm 13.63$ & $40.30 \pm 15.52$ & $34.50 \pm 14.43$ &
\end{tabular}

Ket: Superskrip yang berbeda pada kolom (huruf kapital) dan baris (huruf kecil) yang sama menunjukkan berbeda nyata $(\mathrm{P}<0,01)$.

\section{KESIMPULAN dan SARAN}

\section{Kesimpulan}

Penambahan Larutan Isotonis Komersial dalam pengencer kuning telur dapat dilakukan sebanyak $40 \%$ dengan waktu penyimpanan selama 24 hari pada pengenceran sperma sapi simental dengan nilai motilitas 54\%, spermatozoa hidup hidup $74 \%$, abnormalitas $10 \%$, dan membran plasma utuh sebesar $57 \%$.

\section{Saran}

Larutan Isotonis Komersial dapat digunakan sebagai alternatif pengencer dengan hasil yang terbaik pada persentase LIK $40 \mathrm{ml}$.

\section{DAFTAR PUSTAKA}

Arifiantini, R. I dan T.L. Yusuf.2010. Keberhasilan Penggunaan Tiga Pengencer dalam Dua Jenis Kemasan pada Proses Pembekuan Semen Sapi Frisien Holstein.http://cari-pdf.com/download. Diakses pada tanggal 3 Desember 2015.

Aurich, J. E., U. Schoneher. H. Hoppe and C. Aurich. 1997. Effect of Antioxidands on Motility and Membrane Integrity of Chilled-Stored Stallition Semen. Theriogenology. 48: 185-192.

Bailey, J. M., Dunne, M. P., and Martin, N. G. (2000). The distribution, correlates and determinants of sexual orientation in an Australian twin sample. J. Pers. Soc. Psychol. 78:524-536.

Bardan, Feradis dan T. Adelina. 2009. Penggunaan Air Tebu yang Dikombinasi dengan Kuning Telur sebagai Pengencer Semen Sapi Bali. JurnalPeternakan, 6: 36-43.

Bearden, H. J, and J. W Fuquay. 1984. Applied Animal Reproduction. 2nd edition.Reston Publishing Company, Inc. Virginia.

Damayanti, Y. 1991. Pengaruh Kadar Fruktosa dalam Pengencer Air Kelapa Muda, Aiar Siwalan dan Kombinasinya dengan Kuning Telur terhadap Kualitas Air Mani Ayam Buras. Skripsi. Fakultas Kedokteran Hewan Universitas Airlangga Surabaya. Hal: 33-35.

Hardijantono, S., Suslowatii, T. Sardjito, T. Hernawati, dan T.W. Suprayogi. 2010. Inseminasi Buatan. Fakultas Kedokteran Hewan. Airlangga University Press. Surabaya.

Herdiawan, I. 2004. Pengaruh Laju Penurunan Suhu dan Jenis Pengencer terhadap Kualitas Semen Beku Domba Priangan. Balai Penelitian Ternak.Bogor. JITV. 9(2):98107.

Ichmy, C. 2010. Uji Persentase Motilitas dan Daya Hidup Spermatozoa Domba dengan Pengencer Campuran Larutan Isotonis Komersial dan Kuning Telur. Skripsi. Fakultas Kedokteran Hewan. Universitas Airlangga. Surabaya.

Jayendran, R. S., Van der Van., M. P. Pelaes., B. G. Crabo and L. J. D. Zaneveld. 1984. Development of an Assy to Assess the Functional Integrity of the Human Sperm Membrane and its Relationship on Other Semen Characteristic. J. Reprod. Fertil, 70: 219-228.

Kamal, A. Gubartallah, A. Ahmed, Amel, Bakhiet, dan A. Babiker. 2005. Comparative Studies on Reproductive Performance of 
Nubian and Saanen Buck Under the Climatic Conditions of Khaortum. Journal of Animal and Veterinary Advances. 4(11):942944

Kaya A, N. Baspinar, C. Yilidiz, F. Kurtoglu, M.B. Atman and S. Haliloglu. 2000. Influence of the Seminal Plasma and Plasma Testosteron Levels in Rams. Revue Medicine Veteriner. Turkey. 151(12): 1143-1146

Maxwell, W.M.C and P.F. Watson, 1996.Resent progress in the preservation of ram semen. J. Amin. Reprod. Sci. 42:55-65.

Norman, H.D., R.L. Powel, J.R. Wrigh and CG.Sittler. 2003. Timeliness and effectiveness of progeny Testing Thorght Artificial Insemination. http:/jds.fas.org/cgi/content/abstract/86/4/1513. Diakses 18 November 2015.

Nursyam. 2007. Perkembangan Iptek Bidang Reproduksi Ternak Untuk Meningkatkan Produktifitas Ternak. http://www. scribd.com/doc/ 141993004/ IPTEKREPRODUKSI-TERNAK.Diakses

30 November 2015.

Pocari Sweat, 2015. Komposisi Pocari Sweat.http://www.pocarisweat.com.ph.html Diakses 1 Desember 2015.

Said. S, Gunawan M, Kaiin EM, Tappa B. 2005. Daya Tahan Sperma Cair Sapi Simental yang Disimpan Dalam Straw pada Tempertaur $5^{\circ} \mathrm{C}$. Pusat Penelitian Bioteknologi. LIPI. Buletin peternakan 16: 8-73.

Shukla, M.K. 2011.App Lied Veterinary Andrologiy and Frozen Semen Technology New India Pubsling Ageney. Pitam Pura, New Delhi.

Sinha, S., B.C. Deka, M.K. Tamulu, and B.N. Borgohain. 1996. Effect of Equilibration Period and Glicerol Level In Tris Extender of Quality of Frozen Goat Semen. Indian Vet. J. 69 : 1107-1110.
Solihati, N. dan P.Kune.2009. Pengaruh Jenis Pengencer Terhadap Motilitas dan Daya Hidup Spermatozoa Semen Cair Sapi Simental. Universitas Nusa Candana. Kupang.http://pustaka.unpad.ac.id/. Diakses 1 Desember 2015.

Solihati, N., R. Idi, S.D. Rasad, M. Rizal dan M. Fitriati. 2008. Kualitas spermatozoa cauda epididymis sapi peranakan ongol (PO) dalam pengencer susu, tris dan sitrat kuning telur pada penyimpanan 4-5 o C. J. Anim. Prod. 10 (1) : 22-29

Souhoka D. F., M. J. Matatula., W. Marlene Mesang-Nalley dan M. Rizal. 2009. Laktosa Mempertahankan Daya Hidup Spermatozoa Kambing Peranakan Etawah yang Dipreservasi dengan Plasma Semen Domba Priangan. Fakultas Peternakan, Universitas Nusa Cendana, Nusa Tenggara Timur. Jurnal Veteriner. 10(3):135-142

Sugiarti, T., E. Triwulanningsih, P. Situmorang, R. G. Sianturi, dan D. A. Kusumaningrum. 2004. Penggunaan Katalase dalam Produksi semen dingin sapi. Prosiding Seminar Nasional Teknologi Peternakan dan Vateriner, Bogor. Hal: 215-220.

Susilawati, T., Suyadi, Nuryadi, Isnaini, N, dan Wahyuningsih, S. 1993.Kualitas Semen Sapi Fries Holland dan Sapi Bali Pada Berbagai Umur dan Berat Badan.Laporan Penelitian. Fakultas Peternakan Universitas Brawijaya. Malang.

Toelihere, M.R. 1981. Fisiologi Reproduksi Pada Ternak. Penerbit Angkasa. Bandung. 327 hal.

Toelihere, M.R. 1993. Inseminasi Buatan Pada Ternak. Penerbit Angkasa. Bandung. 292 hal.

Wiyanto, A., I.K.Y. Mas, dan B. Sutiyono. 2014. Pengaruh umur terhadap ukuran testis, volume semen, dan abnormalitas spermatozoa pada Sapi Simental di Balai Inseminasi Buatan Unggaran. Animal Agriculture Journal, 3(2):292-299. 